\title{
Bacterial Detoxification of Copper and Its Impacts on Germination Indices of Barley and Mung Bean
}

\author{
D. E. M. Radwan ${ }^{1,3}$, A. M. M. Essa ${ }^{2,3}$ M. N. Awad ${ }^{3}$ \\ ${ }^{1}$ Botany Department, Faculty of Science, Sohag University, \\ Sohag, ,2 Botany Department, Faculty of Science, Fayoum \\ University, Fayoum, Egypt and ${ }^{3}$ Biology Department, Faculty \\ of Science, Jazan University, Kingdom of Saudi Arabia
}

\begin{abstract}
O N ACCOUNT of incessant human activities, copper is accumulated in the environment at elevated concentrations that induce harmful influences on all kinds of living organisms. An oxic bioreactor was employed to transform copper ions into copper particles using volatile metabolites of Escherichia coli culture. SEM and EDX analysis of the transformed copper showed the formation of elongated particles with $1-5 \mu \mathrm{m}$ in length comprising of copper, sulfur, carbon, oxygen and nitrogen elements. Mung bean seeds and barley grains exposed to ionic copper demonstrated low germination and apparent decline of seedlings growth parameters while higher germination and growth rates were recorded with those treated with copper particles. At the same time, an enhanced POD activity was noticed with all $\mathrm{Cu}$ treatments, CAT activity seemed to be induced in response to ionic $\mathrm{Cu}$ only meanwhile APX activity was markedly affected with both types of $\mathrm{Cu}$. Furthermore, seedlings subjected to $\mathrm{Cu}$ particles showed higher protein contents. Toxicity reduction of copper treated with $E$. coli volatiles was ascribed to the decrease of the mobile copper concentration as a result of interaction with vaporized chelators that reduce bioavailability of copper.
\end{abstract}

Keywords: Copper - Detoxification - E. coli - Antioxidant enzymes Hordeum vulgare - Vigna radiata.

At the moment, there is an extensive raise in the discharge of industrial effluents into the environment, primarily soil and water that generally leads to the accumulation of heavy metals. Heavy metals pollution is a major health concern since they are non-degradable and have long-lasting effects on the ecosystem. Heavy metals discharge from industrial activities is considered common source of heavy metal pollution such as fertilizer production, electroplating and plastics manufacturing in addition to mining and metallurgical processes (Zouboulis et al., 2004). Most heavy metals such as arsenic, cadmium, chromium, copper, lead, mercury, nickel, silver, zinc are toxic to all living organisms even at very low concentrations. Toxic consequences of excess levels of heavy metals in

${ }^{1}$ Corresponding author:Tel.: +2-093-4611042; Fax: +2-093-4601159 E-mail address: deya90@yahoo.com (D. Radwan). 
plants include cellular damage and production of elevated amounts of reactive oxygen species (ROS)-led to oxidative stress, and cellular metabolic arrest (Gill and Tuteja, 2010). At relatively low concentrations, a number of heavy metal such as $\mathrm{Co}^{2+}, \mathrm{Cu}^{2+}, \mathrm{Fe}^{2+}, \mathrm{Mn}^{2+}, \mathrm{Mo}^{2+}, \mathrm{Ni}^{2+}$, and $\mathrm{Zn}^{2+}$ are recognized as essential trace elements for living cells as they act as cofactors of metalloproteins and some enzymes (Jansen et al., 1994). These metals can also modulate plant ROSmetabolizing/scavenging system that comprising of enzymatic such as catalase, guaiacol peroxidase, glutathione sulfotransferase, ascorbate peroxidase, monodehydroascorbate reductase, glutathione reductase, dehydroascorbate reductase and non-enzymatic such as ascorbate, glutathione, carotenoids, tocopherols, and phenolics (Anjum et al., 2012).

Although copper is required for normal cell growth, it is considered as a common soil contaminant. It is growing environmental problem due to the continuity of human activities leading to copper pollution. These activities include mining, sewage sludge application to soils and copper containing fungicides (Mackie et al., 2012 and Ruyters et al., 2013).

The ionic form of $\mathrm{Cu}^{2+}$ caused root growth alterations in durum wheat at low concentration; $1.0 \mu \mathrm{M}$ and high $\mathrm{Cu}$ concentrations $(200$ and $500 \mu \mathrm{M})$ may reduce the growth of both root and shoots (Michaud et al., 2008 and Thounaojam et al., 2014). Toxicity of $\mathrm{Cu}$ is affected by bioavailability of metal in the soil and by the concentration of the metal as well as $\mathrm{pH}$ of the soil (Wang et al., 2009). High concentration of $\mathrm{Cu}^{2+}$ are toxic and leads to inhibition of plant growth, disturbance of the mitosis, inhibition of root elongation, damage to root cell membranes (Ouzounidou et al., 1995). Cu tends to be accumulated in the root tissue with little translocate to the shoots (Marschner, 1995).

The capability of microbial cells to stay alive in the occurrence of elevated doses of heavy metals could be assigned to the occurrence of various strategies to accommodate with these fatal pollutants. Of these mechanisms is the aptitude of the microbial cell to discharge non-specific extracellular molecules that are engaged in the attenuation of heavy metals toxicity through altering the physicochemical conditions around microbial biomass. Such these modifications induce the bioprecipitation of these pollutants in the microbial surroundings (Fomina et al., 2008; Dupraz et al., 2009 and Jang et al., 2015).

It is well known that plants produce root exudates containing an assortment of organic substances which have considerable consequences on the development of microbial communities and their activities. Therefore, the interaction between plant roots and soil microbes can influence on the mobilization and immobilization of metals in the soil (Seshadri et al., 2015). Protection of plants from the toxicity of heavy metals such as copper, zinc and lead occurs through microbial changing metal speciation into biologically unavailable species (He and Yang, 2007; Huang et al., 2005 and Dixit et al., 2015). Thus the aim of the present study was to evaluate the impact of ionic

Egypt. J. Bot., Vol. 56, No. 3 (2016) 
copper and copper treated with the volatile metabolites of $E$. coli on seed germination and metabolism of barley and mung bean seedlings.

\section{Materials and Methods}

\section{Treatment of $\mathrm{CuSO}_{4}$ by bacterial volatiles}

Two concentrations of copper sulfate $\left(\mathrm{CuSO}_{4} \cdot 5 \mathrm{H}_{2} \mathrm{O}\right)$ solutions $(0.2 \mathrm{mM}$ and $0.4 \mathrm{mM}$ ) were prepared from stock solution $\left(1.0 \mathrm{M} \mathrm{CuSO}_{4}\right)$. The bacterial strain, Escherichia coli, (Essa, 2012) was used in this study. It was grown aerobically in Luria Broth medium on shaking incubator $(200 \mathrm{rpm})$ for $24 \mathrm{hr}$ at $30{ }^{\circ} \mathrm{C}$. Bacterial growth was monitored by measuring the optical density at $600 \mathrm{~nm}$. Two sets of the $\mathrm{CuSO}_{4}$ solutions, $(200 \mathrm{ml}$ of each) were exposed to the E. coli biogases (OD $\approx 0.8$ ) for $24 \mathrm{hr}$ in an oxic bioreactor according to Essa et al. (2012). Then one set of the treated copper solutions were used to study their effect on seed germination and seedlings growth criteria while the other set was subjected for centrifugation at $10000 \mathrm{rpm}$ for $15 \mathrm{~min}$. The supernatant was discarded and precipitates were washed with $20 \mathrm{ml}$ deionized water followed by centrifugation as before. The last step was repeated three times and $\mathrm{Cu}$-precipitate were collected and dried at $30{ }^{\circ} \mathrm{C}$. Cu-precipitates were examined with a JEOL JSM 5900 scanning electron microscope with the elemental composition determined by energy dispersive X-ray microanalysis (EDX) using an Oxford Link ISIS System according to Essa and Khallaf (2014).

\section{Plant materials and treatments}

Mung bean (Vigna radiata; Fabaceae) seeds and barley (Hordeum vulgare; Poaceae) grains were surface sterilized by immersion in ethyl alcohol (70\%) for 2 min followed by rinsing three times with sterilized deionized water, 5 minutes each. Surface sterilized seeds or grains were germinated in $10 \mathrm{~cm}$ plastic Petri dishes containing sterilised filter papers witted with $20 \mathrm{ml}$ of treatment solutions, 10 seeds or grains in per dish where control dishes contained $20 \mathrm{ml}$ of sterilized water. Triplicates of each treatment were done and all dishes were kept in the dark at $18 \pm 20^{\circ} \mathrm{C}$.

The treatments were carried out as following:

1) Control: sterilized deionized water.

2) $\mathrm{Cu}$-IL: Ionic $\mathrm{Cu}$ solution $\left(\mathrm{CuSO}_{4} \cdot 5 \mathrm{H}_{2} \mathrm{O}\right)$ at low concentration $(8 \mu \mathrm{M})$.

3) $\mathrm{Cu}-\mathrm{NL}$ : $\mathrm{Cu}$-particles solution prepared via E. coli volatile metabolites at low concentration $(8 \mu \mathrm{M})$.

4) $\mathrm{Cu}-\mathrm{IH}$ : Ionic $\mathrm{Cu}$ solution $\left(\mathrm{CuSO}_{4} \cdot 5 \mathrm{H}_{2} \mathrm{O}\right)$ at high concentration $(16 \mu \mathrm{M})$.

5) $\mathrm{Cu}-\mathrm{NH}$ : $\mathrm{Cu}$-particles solution prepared via $E$. coli volatile metabolites at high concentration $(16 \mu \mathrm{M})$.

Analysis of growth parameters

The percentage of germinated seeds or grains, length of seedlings (in centimetres), fresh weight and dry weight of seedlings were determined to express metal toxicity in both ionic and non-ionic $\mathrm{Cu}$ forms. 
Antioxidant enzymes

All extraction procedures were carried out at $4{ }^{\circ} \mathrm{C}$, where one gram of fresh seedlings was grinded in $5 \mathrm{ml}$ of phosphate buffer $\mathrm{pH} 7.0$ followed by centrifugation at $14000 \mathrm{~g}$ at $10{ }^{\circ} \mathrm{C}$ for $15 \mathrm{~min}$. The supernatants were used for determination of enzyme activity.

Peroxidase activity (POD)

For determination of POD (EC 1.11.1.7) activity, supernatants $(0.1 \mathrm{ml})$ were mixed with assay mixture $(3 \mathrm{ml})$ and the development of the brown color was monitored. The assay mixture for POD activity contained $40 \mathrm{mM}$ potassium phosphate $\mathrm{pH} 7.2,0.1 \mathrm{mM}$ EDTA, $5 \mathrm{mM}$ guaiacol, $0.3 \mathrm{mM} \mathrm{H}_{2} \mathrm{O}_{2}$. The increase in the absorbance due to oxidation of guaiacol (Extinction factor $=26.2 \mathrm{mM} \mathrm{cm}^{-}$ ${ }^{1}$ ) was measured spectrophotometrically at $470 \mathrm{~nm}$. POD activity was calculated in terms of $\mu \mathrm{mol}$ of guaiacol oxidized $\mathrm{min}^{-1} \mathrm{~g}^{-1}$ Fresh weight at $25 \pm 2{ }^{\circ} \mathrm{C}$ (MacAdam et al., 1992; Zhang, 1992).

\section{Catalase activity (CAT)}

By monitoring the disappearance of $\mathrm{H}_{2} \mathrm{O}_{2}$, CAT (EC 1.11.1.6) activity was measured according to the method of Chandlee and Scandalios (1984). The disappearance of $\mathrm{H}_{2} \mathrm{O}_{2}$ was measured by the decrease in absorbance at $240 \mathrm{~nm}$ $\left(E=0.036 \mathrm{mM}^{-1} \mathrm{~cm}^{-1}\right)$ of a reaction mixture $(3 \mathrm{ml})$ consisting of $25 \mathrm{mM}$ potassium phosphate buffer $(\mathrm{pH} 7.0), 10 \mathrm{mM} \mathrm{H}_{2} \mathrm{O}_{2}$ and enzyme extract $(0.1 \mathrm{ml})$. One CAT unit is the amount of enzyme necessary to decompose $1 \mu \mathrm{mol} \mathrm{min}{ }^{-1}$ $\mathrm{H}_{2} \mathrm{O}_{2}$ under the above-mentioned assay conditions.

\section{Ascorbate peroxidase activity (APX)}

APX (EC 1.11.1.11) activity was determined according to Nakano and Asada (1981). The supernatants were mixed with the assay medium for testing the activity of APX. The assay medium consists of $3 \mathrm{ml}$ containing $50 \mathrm{mM}$ phosphate buffer ( $\mathrm{pH} 7.0$ ), $0.1 \mathrm{mM}$ EDTA, $0.3 \mathrm{mM}$ ascorbate, $0.06 \mathrm{mM} \mathrm{H}_{2} \mathrm{O}_{2}$ and $0.1 \mathrm{ml}$ enzyme extract. The decrease in ascorbate concentration was followed by decline in absorbance at $290 \mathrm{~nm}$ and activity was calculated using the extinction coefficient $\left(E=2.8 \mathrm{mM}^{-1} \mathrm{~cm}^{-1}\right)$ for ascorbate.

\section{Protein content}

Soluble, insoluble and total protein contents of seedlings were determined according to Lowry et al. (1951). Dry tissues were extracted in $10 \mathrm{ml}$ distilled water for $2 \mathrm{hr}$ at $90{ }^{\circ} \mathrm{C}$ for analysis of soluble protein. Moreover, the total proteins were extracted in $10 \mathrm{ml} \mathrm{NaOH}(0.1 \mathrm{~N})$ for $2 \mathrm{hr}$ at $90{ }^{\circ} \mathrm{C}$. The extracts were centrifuged and the supernatants were collected. One $\mathrm{ml}$ of extract was added to $5 \mathrm{ml}$ of alkaline reagent $\left(50 \mathrm{ml}\right.$ of $2 \% \mathrm{Na}_{2} \mathrm{CO}_{3}$ prepared in $0.1 \mathrm{~N} \mathrm{NaOH}$ and $1 \mathrm{ml} 0.5 \%$ of $\mathrm{CuSO}_{4} .5 \mathrm{H}_{2} \mathrm{O}$ prepared in $1 \%$ sodium potassium tartrate), mixed thoroughly and then allowed to stand for $10 \mathrm{~min}$. Folin reagent diluted 1:1 $(\mathrm{v} / \mathrm{v})$ was then added and mixed immediately. After $30 \mathrm{~min}$, the extinction against appropriate blank was measured at $700 \mathrm{~nm}$. Results were expressed as milligrams per gram dry weight. Insoluble proteins were calculated as the

Egypt. J. Bot., Vol. 56, No. 3 (2016) 
difference between the amounts of total and water-soluble proteins. Bovine serum albumin was used for calibration curve.

\section{Total free amino acids content}

According to Moore and Stein (1948), total free amino acids were extracted and determined. Dry tissue samples were extracted in distilled water by heating in water bath at $90{ }^{\circ} \mathrm{C}$ for $2 \mathrm{hrs}$. The extracts were then centrifuged and the supernatants were collected. Supernatant $(0.1 \mathrm{ml})$ was added to $1 \mathrm{ml}$ of ninhydrin solution with stannous chloride. The tubes were heated in boiling water bath for 20 min till a purple color was developed. Five milliliter of the diluents were added and mixed well. After $15 \mathrm{~min}$, the intensity of the color against a reagent blank was measured in a colorimeter at $570 \mathrm{~nm}$. The free amino acids concentrations were calculated as $\mathrm{mg} / \mathrm{g}$ dry matter.

\section{Statistical analyses}

The resulted data were tested by using the ANOVA test for significance. Means were compared by least significant differences (LSD) test at levels $P$ $<0.05$ and $P<0.01$. All statistical tests were carried out using SPSS (v. 16.0) software (Garth, 2008).

\section{Results}

\section{Effect of E. coli biogas on $\mathrm{CuSO}_{4}$ solution}

Data in Table 1 showed that changes in the optical density (OD), $\mathrm{pH}$ and color of $\mathrm{CuSO}_{4}$ solutions in the precipitation chamber of the bioreactor as a result of exposing to the volatiles produced aerobically by $E$. coli. There was a gradual increase in the $\mathrm{OD}$ and $\mathrm{pH}$ values of copper solution by increasing the exposure time where maximum OD was recorded after $12 \mathrm{hr}$ with $\mathrm{pH}$ value 8.2. After 24 hr exposure time, the $\mathrm{pH}$ value reached the highest value (8.8) and a pale blue precipitate was formed. At the same time, there was a marked change in the color of $\mathrm{CuSO}_{4}$ solution by increasing the exposure time until $24 \mathrm{hr}$ where pale blue precipitate was formed. Scanning electron microscope analysis of the $\mathrm{Cu}$ precipitate (Fig. 1) showed the formation of elongated particles with $1-5 \mu \mathrm{m}$ in length. At the same time, electron dispersive X-ray analysis of these particles elucidated their elemental composition. They comprised of $61.71 \%$ copper, $8.44 \%$ sulfur, $4.03 \%$ carbon, $22.19 \%$ oxygen and $1.98 \%$ nitrogen (Fig. 1).

\section{Analysis of growth parameters}

The germination of both mung bean seeds and barley grains under the effect of $\mathrm{Cu}$ treatment was presented in Fig. 2. Compared to control, all treatments could reduce the growth of seedlings at variable levels. The effect of $\mathrm{Cu}$ toxicity was more obvious in radicals than plumules. In case of mung bean seedlings, radicals become reduced and totally inhibited in barley seedlings. Non-ionic $\mathrm{Cu}$ form seemed to be less toxic than the ionic form of $\mathrm{Cu}$ in both low and high $\mathrm{Cu}$ concentrations. 
TABLE 1. Influence of exposure time of $E$. coli volatiles on the physical characters of copper sulfate solution in the precipitation chamber of the oxic bioreactor.

\begin{tabular}{|l|c|c|c|}
\hline Exposure time (hrs) & $\mathbf{O . D}_{\mathbf{6 0 0}}$ & $\mathbf{p H}$ & Color \\
\hline 0 & 0.000 & 6.3 & Blue \\
\hline 2 & 0.069 & 6.5 & Blue \\
\hline 4 & 0.113 & 7.4 & Turbid blue \\
\hline 8 & 0.437 & 7.8 & Cloudy blue \\
\hline 12 & 0.792 & 8.2 & Light blue precipitate \\
\hline 24 & 0.547 & 8.8 & Pale blue precipitate \\
\hline
\end{tabular}

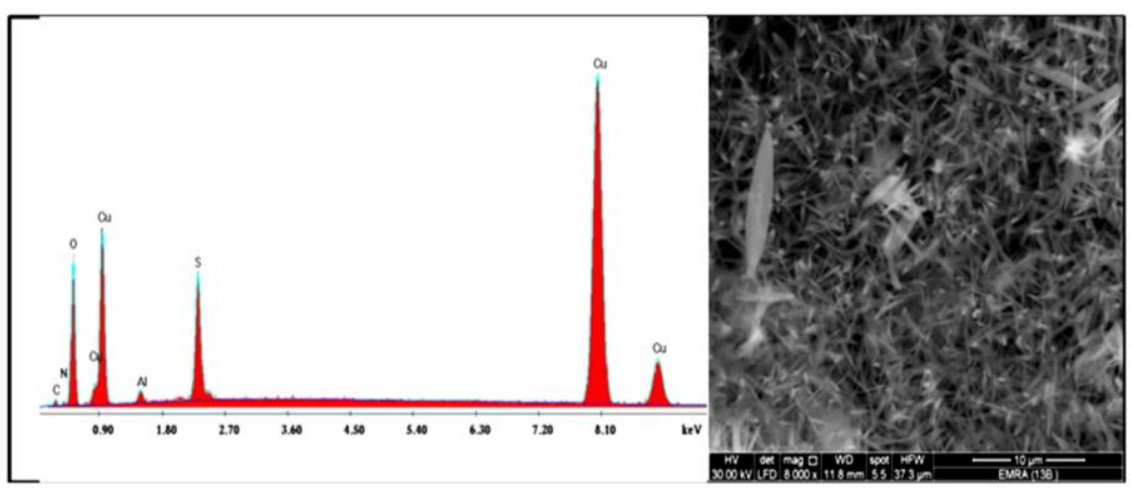

Fig. 1. Scanning electron microscope (SEM) and energy dispersive X-ray (EDX) analysis of copper particles produced in the bioreactor through the interaction of volatile metabolites of $E$. coli culture with copper sulfate solution.

The percentage of seed or grain germination was affected by $\mathrm{Cu}$ application in either ionic or non-ionic form (Fig. 3). $\mathrm{Cu}$ could lower the percentage of germination and the reduction depended on $\mathrm{Cu}$ concentration, the higher $\mathrm{Cu}$ concentration the lower the percentage of germination. Different percentages of germination were obtained in different forms of $\mathrm{Cu}$. In mung beans, the percentage of germination at low $\mathrm{Cu}$ were $53 \%$ and $73 \%$ in case of ionic and non-ionic $\mathrm{Cu}$ forms, respectively. Almost similar responses were detected in barely grains germinated in ionic and non-ionic $\mathrm{Cu}$ forms. Results concerning the percentage of germination revealed that, the toxicity of $\mathrm{Cu}$ was lower in case of non-ionic $\mathrm{Cu}$ for the same concentration in both plants.

The length of seedlings produced in all $\mathrm{Cu}$ treatments was reduced (Fig 3). The severity of reduction was concentration and $\mathrm{Cu}$-form dependent. In all concentrations, the non-ionic $\mathrm{Cu}$ form was less toxic to both mung bean and barely seedlings. Compared to the control, low concentration caused reduction of $57 \%$ and $90 \%$ in cases of mung bean treated with low and high concentration of ionic $\mathrm{Cu}$, respectively. Barley seedlings grown on high non-ionic $\mathrm{Cu}$ were $65 \%$ Egypt. J. Bot., Vol. 56, No. 3 (2016) 
longer than those germinated on high ionic $\mathrm{Cu}$. Moreover, in case of mung bean seedlings, high ionic and non-ionic $\mathrm{Cu}$ concentrations reduced seedling lengths to $92 \%$ and $47 \%$ less than control, respectively.

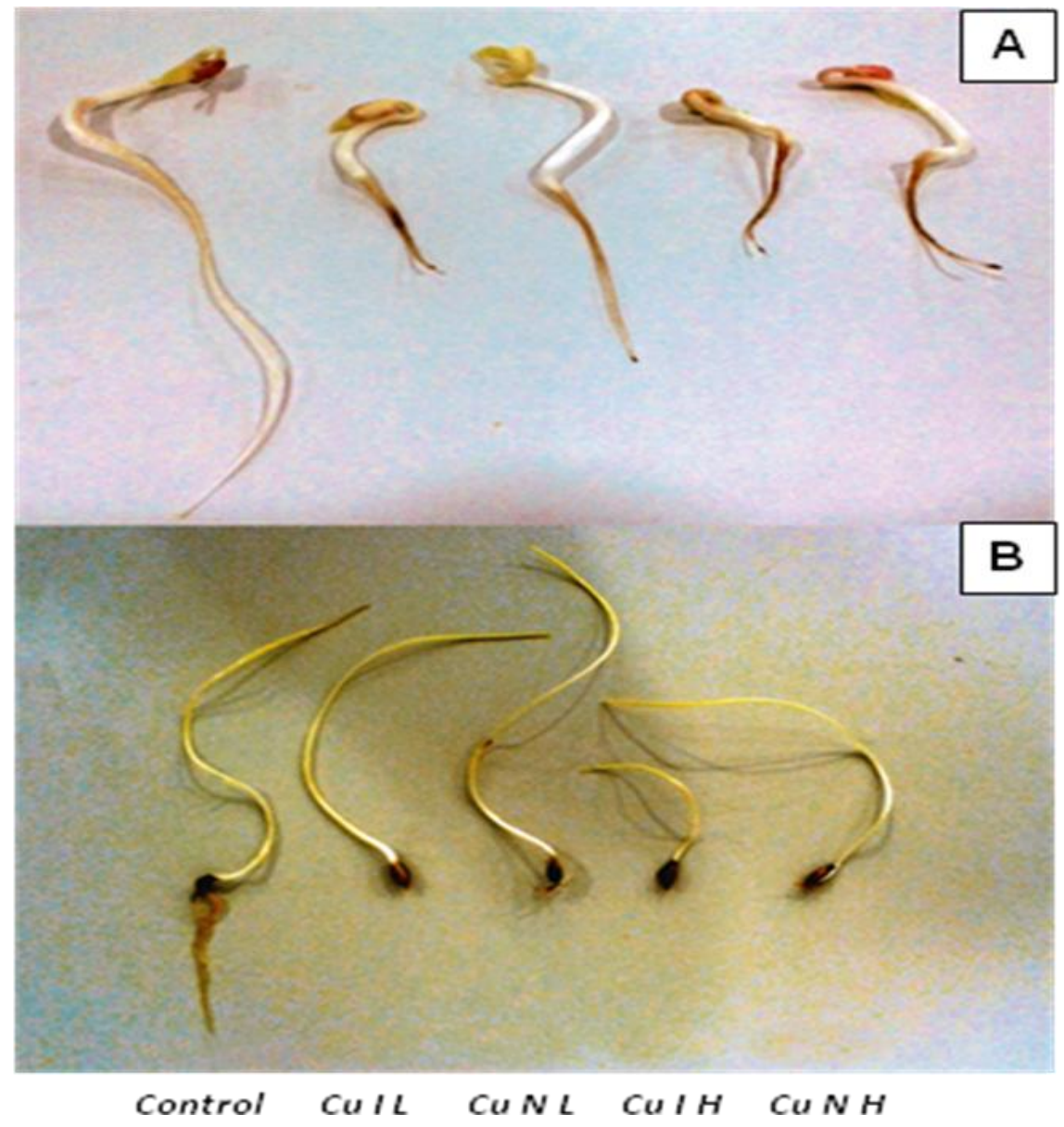

Fig. 2. Impact of ionic and non-ionic copper on the germination of mung bean seeds (Vigna radiate; A) and barley grains (Hordeum vulgare; B). 


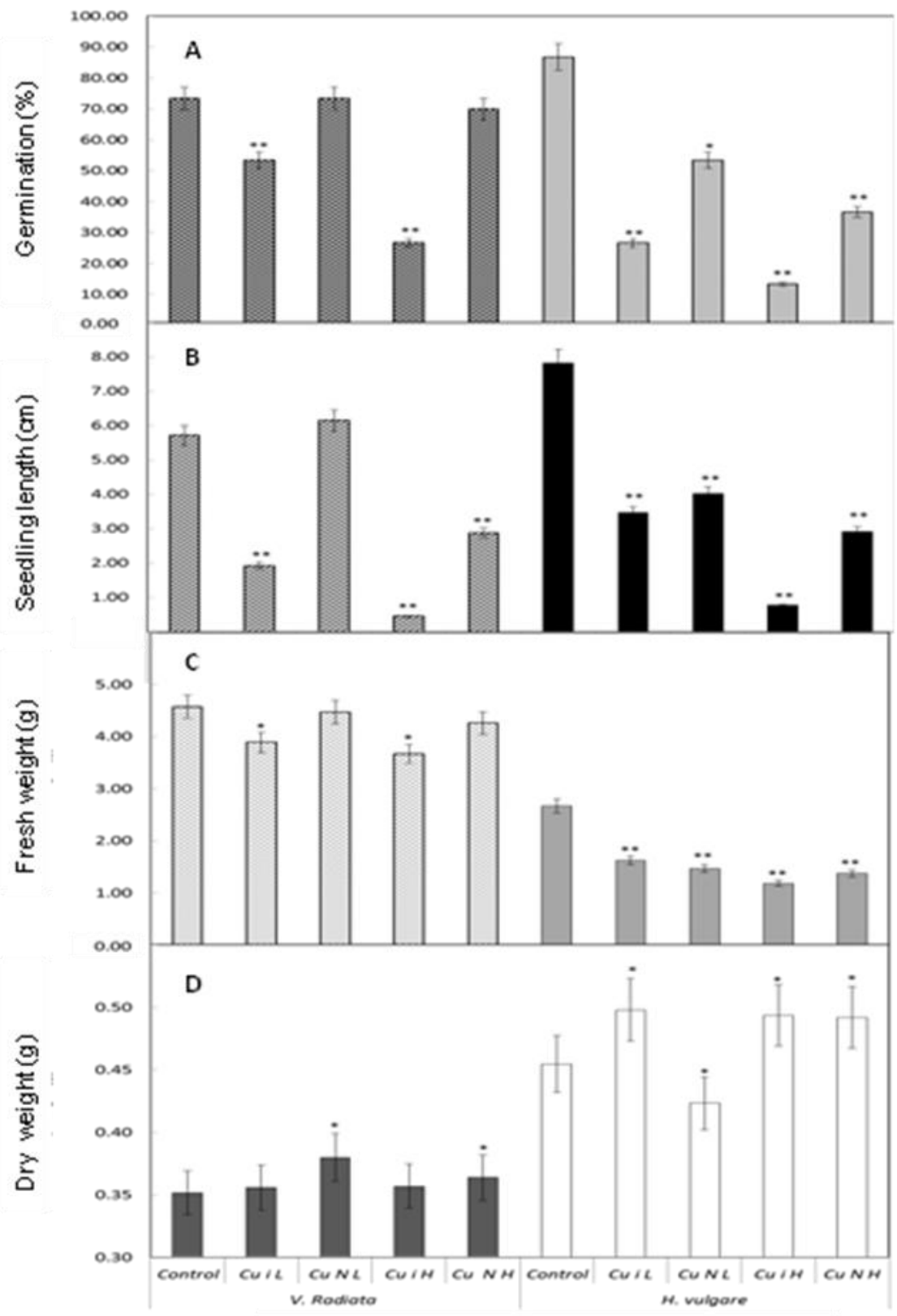

Fig. 3. Growth parameters of mung bean seeds (Vigna radiata) and barley grains (Hordeum vulgare) germinated on ionic and non-ionic $\mathrm{Cu}$-solutions where (A) is germination percentage, (B) is seedling length, (C) is fresh weight and (D) is dry weight.

Egypt. J. Bot., Vol. 56, No. 3 (2016) 
Comparing the weights (fresh and dry) of the produced seedlings under stressful conditions with the corresponding controls, the obtained results demonstrated lower weights of seedlings due to $\mathrm{Cu}$ treatments. Similarly, $\mathrm{Cu}$ toxicity leads to reduced fresh and dry weights in case of ionic $\mathrm{Cu}$ in low and high concentrations in both plants. On the other hand, non-ionic $\mathrm{Cu}$ showed less of no toxicity in mung bean where the fresh and dry weights were almost similar to controls.

\section{Antioxidant enzymes analyses}

The analyzed antioxidant enzymes peroxidase (POD), Catalase (CAT) and Ascorbate peroxidase (APX) extracted from both mung bean and barely seedling grown for 10 days on different $\mathrm{Cu}$ treatments were tested for their activities. Alterations in enzyme activities were detected in response to different forms of $\mathrm{Cu}$ as well as different plants (Table 2). Comparing the controls, POD extracted from barely was 10 fold more active than mung bean POD. Peroxidase activity was enhanced in seedlings grown on all $\mathrm{Cu}$ treatments. High concentration of non-ionic $\mathrm{Cu}$ could induce the activity of POD to be $390 \%$ and $102 \%$ more than control for mung bean and barely, respectively. Peroxidase activity was induced with lesser amounts in non-ionic $\mathrm{Cu}$ treatments compared with the corresponding ionic forms. For high concentration of non-ionic $\mathrm{Cu}$, POD activity increased with percentages of $50 \%$ and $89 \%$ for mung bean and barley, respectively. $\mathrm{Cu}$ in nonionic form could lower the POD activities compared with the corresponding ionic forms but still the values higher than those of the controls.

Catalase activity was lowered by subjection to $\mathrm{Cu}$ in most treatments. In comparison to control, low concentration of ionic $\mathrm{Cu}$ could lower the activity of CAT to be $98 \%$ and $49 \%$ for mung bean and barely, respectively. In case of nonionic $\mathrm{Cu}, \mathrm{CAT}$ activity increased by $9 \%$ and $7 \%$ for low and high concentrations in mung bean. On the other plant, the increase reached $6 \%$ and $15 \%$ above control in case of low and high concentration of non-ionic $\mathrm{Cu}$ applied to barley seedlings. Compared to the other analyzed enzymes, the effect of $\mathrm{Cu}$ treatments on CAT activity was less in both plants.

Ascorbate peroxidase (APX) activity showed similar behavior as peroxidase in its response towards $\mathrm{Cu}$ in its different forms. In details, high concentration of non-ionic $\mathrm{Cu}$ induced the activity of APX to be $176 \%$ and $332 \%$ above controls in case of mung bean and barely, respectively. Non-ionic $\mathrm{Cu}$ form reduced the activity of APX to be $9 \%$ in mung bean and double folded the activity in barely compared with their controls. Generally, non-ionic $\mathrm{Cu}$ had less effect on the activity of $A P X$ than ionic $\mathrm{Cu}$.

\section{Proteins and amino acids}

Soluble, insoluble and total proteins were determined for mung bean and barley seedlings (Table 3). The obtained data revealed that soluble, insoluble and total proteins were lowered with all $\mathrm{Cu}$ treatments in both plants. On exception, low non-ionic $\mathrm{Cu}$ could increase the soluble, insoluble and total proteins content 
in barely seedlings while high non-ionic $\mathrm{Cu}$ form increased the soluble protein only. It seemed that non-ionic $\mathrm{Cu}$ could increase the protein contents compared with ionic $\mathrm{Cu}$. Meanwhile, soluble and total proteins were induced by non-ionic $\mathrm{Cu}$ in barely seedlings where the values reached $130 \%$ and $121 \%$ for soluble and total proteins, respectively when seedlings were germinated in low concentration of non-ionic $\mathrm{Cu}$. There are slight differences between the effect of low and high concentrations of ionic $\mathrm{Cu}$ on total protein contents in mung bean whereas in barely it was found that the higher the concentration of ionic $\mathrm{Cu}$ the lower the total proteins content.

TABLE 2. Effect of ionic and non-ionic Cu treatments on antioxidant enzymes (Unit $\mathrm{g}^{-1} \mathrm{FW}$ ) of Vigna radiata and Hordeum vulgare seedlings. Values are means (M) of four replicates \pm standard deviation (SD).

\begin{tabular}{|c|c|c|c|c|c|c|c|c|c|c|c|c|c|}
\hline \multirow{2}{*}{ Plants } & \multirow{2}{*}{ Treatments } & \multicolumn{4}{|c|}{$P O D$} & \multicolumn{4}{|c|}{$C A T$} & \multicolumn{4}{|c|}{$A P X$} \\
\hline & & M & & D & $\%$ & M & & D & $\%$ & $\mathbf{M}$ & & $\mathbf{D}$ & $\%$ \\
\hline \multirow{5}{*}{ 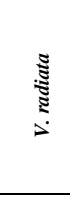 } & Control & 19.34 & \pm & 4.58 & 100.00 & 25.80 & \pm & 8.40 & 100.00 & 19.97 & \pm & 2.05 & 100.00 \\
\hline & $\mathrm{Cu}-\mathrm{IL}$ & $35.37^{* * *}$ & \pm & 7.29 & 182.89 & 25.20 & \pm & 7.85 & 97.67 & $12.15 *$ & \pm & 0.82 & 60.87 \\
\hline & Cu-NL & $29.77^{* * *}$ & \pm & 1.82 & 153.95 & $28.20 *$ & \pm & 9.00 & 109.30 & $13.76^{* * *}$ & \pm & 0.41 & 68.90 \\
\hline & $\mathrm{Cu}-\mathrm{IH}$ & $94.85^{* *}$ & \pm & 2.62 & 490.46 & 26.20 & \pm & 1.79 & 101.55 & $55.27 * *$ & \pm & 6.14 & 276.81 \\
\hline & $\mathrm{Cu}-\mathrm{NH}$ & $28.94 * *$ & \pm & 7.61 & 149.67 & 27.60 & \pm & 2.16 & 106.98 & $16.08 * *$ & \pm & 2.05 & 80.43 \\
\hline \multirow{5}{*}{ 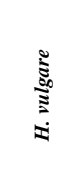 } & Control & 188.10 & \pm & 3.13 & 100.00 & 19.50 & \pm & 4.95 & 100.00 & 9.84 & \pm & 4.09 & 100.00 \\
\hline & Cu-IL & $320.55^{* * *}$ & \pm & 9.56 & 170.41 & 19.30 & \pm & 0.71 & 98.97 & $19.97 * *$ & \pm & 0.41 & 202.94 \\
\hline & $\mathrm{Cu}-\mathrm{NL}$ & $300.64 * *$ & \pm & 6.72 & 159.82 & 20.56 & \pm & 4.24 & 105.44 & $16.94 *$ & \pm & 4.09 & 70.59 \\
\hline & $\mathrm{Cu}-\mathrm{IH}$ & $379.58^{* *}$ & \pm & 3.76 & 201.79 & $25.73 * *$ & \pm & 5.66 & 131.95 & $42.53 * *$ & \pm & 4.50 & 432.35 \\
\hline & $\mathrm{Cu}-\mathrm{NH}$ & $353.88^{* *}$ & \pm & 3.97 & 188.13 & $22.38^{*}$ & \pm & 1.41 & 114.77 & $20.25^{* *}$ & \pm & 6.55 & 205.88 \\
\hline
\end{tabular}

Statistical significance of differences compared to control: *, significant at $P<0.05$; **, significant at $P<0.01$.

TABLE 3. Effect of ionic and non-ionic $\mathrm{Cu}$ treatments on soluble, insoluble and total proteins (mg $\mathrm{g}^{-1} \mathrm{FW}$ ) of Vigna radiata and Hordeum vulgare seedlings. Values are means (M) of four replicates \pm standard deviation $(\mathrm{SD})$.

\begin{tabular}{|c|c|c|c|c|c|c|c|c|c|c|c|c|c|}
\hline \multirow{2}{*}{ Plants } & \multirow{2}{*}{ Treatments } & \multicolumn{4}{|c|}{ Soluble proteins } & \multicolumn{4}{|c|}{ Insoluble proteins } & \multicolumn{4}{|c|}{ Total proteins } \\
\hline & & $\mathbf{M}$ & & SD & $\%$ & $\mathbf{M}$ & & SD & $\%$ & $\mathbf{M}$ & & SD & $\%$ \\
\hline \multirow{5}{*}{ 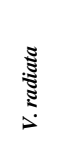 } & Control & 127.73 & \pm & 7.02 & 100.00 & 171.93 & \pm & 3.73 & 100.00 & 299.67 & \pm & 5.70 & 100.00 \\
\hline & Cu-IL & $94.53^{* * *}$ & \pm & 6.74 & 74.01 & 108.80 ** & \pm & 2.32 & 63.28 & $203.33^{* * *}$ & \pm & 8.04 & 67.85 \\
\hline & Cu-NL & $107.73^{*}$ & \pm & 9.98 & 84.34 & $107.27 * *$ & \pm & 8.41 & 62.39 & $215.00^{\text {*** }}$ & \pm & 3.61 & 71.75 \\
\hline & $\mathrm{Cu}-\mathrm{IH}$ & $94.27^{* * *}$ & \pm & 3.14 & 73.80 & $118.40^{* * *}$ & \pm & 4.74 & 68.86 & $212.67^{* * *}$ & \pm & 3.32 & 70.97 \\
\hline & Cu-NH & $112.93^{*}$ & \pm & 4.80 & 88.41 & $89.73 * *$ & \pm & 2.59 & 52.19 & $202.67 * *$ & \pm & 4.39 & 67.63 \\
\hline \multirow{5}{*}{ 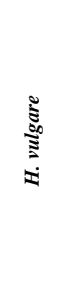 } & Control & 58.67 & \pm & 9.26 & 100.00 & 146.00 & \pm & 3.07 & 100.00 & 204.67 & \pm & 2.82 & 100.00 \\
\hline & $\mathrm{Cu}-\mathrm{IL}$ & 54.27 & \pm & 6.65 & 92.50 & 137.40 & \pm & 6.36 & 94.11 & $191.67 *$ & \pm & 7.32 & 93.65 \\
\hline & $\mathrm{Cu}-\mathrm{NL}$ & $75.73 * *$ & \pm & 1.52 & 129.09 & $171.27 * *$ & \pm & 5.72 & 117.31 & 207.00 & \pm & 8.54 & 120.68 \\
\hline & $\mathrm{Cu}-\mathrm{IH}$ & $96.53 * *$ & \pm & 3.89 & 164.55 & $62.13 * *$ & \pm & 4.66 & 42.56 & $158.67 *$ & \pm & 7.50 & 77.52 \\
\hline & $\mathrm{Cu}-\mathrm{NH}$ & $65.87^{* * *}$ & \pm & 1.59 & 112.27 & $107.47^{*}$ & \pm & 4.69 & 73.61 & $173.33 *$ & \pm & 3.50 & 84.69 \\
\hline
\end{tabular}

Statistical significance of differences compared to control: *, significant at $P<0.05$; **, significant at $P<0.01$.

Egypt. J. Bot., Vol. 56, No. 3 (2016) 
Total free amino acids of control and $\mathrm{Cu}$ treated seedlings of mung bean and barley after 10 days of germination were shown in Table 4. Free amino acids were increased in most of $\mathrm{Cu}$ treatments by $5-40 \%$ above the corresponding controls. The ionic forms of $\mathrm{Cu}$ could increase the total free amino acids in both mung bean and barley. In case of mung bean, the increase caused by low and high ionic $\mathrm{Cu}$ was 10 and 40\%. Similarly in barley seedlings, low and high concentrations of ionic $\mathrm{Cu}$ increased the total free amino acids by 15 and $19 \%$ more than controls. Non-ionic $\mathrm{Cu}$ could keep the content of total free amino acids more or less than controls in both mung bean and barley seedlings. The values were 89 and $103 \%$ in case of mung bean and barley at high concentration of non-ionic $\mathrm{Cu}$. It can be concluded that ionic forms could induce more contents of free amino acids while non-ionic $\mathrm{Cu}$ form could keep the values almost similar to those of the corresponding controls.

TABLE 4. Effect of ionic and non-ionic $\mathrm{Cu}$ treatments on total free amino acids $\left(\mathrm{mg} \mathrm{g}^{-1}\right.$ FW) of Vigna radiata and Hordeum vulgare seedlings. Values are means (M) of four replicates \pm standard deviation (SD).

\begin{tabular}{|c|c|c|c|c|c|}
\hline \multirow{2}{*}{ Plants } & \multirow{2}{*}{ Treatments } & \multicolumn{4}{|c|}{ Total free amino acids } \\
\hline & & $\mathbf{M}$ & & SD & $\%$ \\
\hline \multirow{5}{*}{ 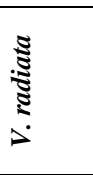 } & Control & 29.96 & 1 & 4.10 & 100.00 \\
\hline & $\mathrm{Cu}-\mathrm{IL}$ & $33.1 *$ & 1 & 2.76 & 110.48 \\
\hline & $\mathrm{Cu}-\mathrm{NL}$ & 31.74 & 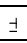 & 3.63 & 105.94 \\
\hline & $\mathrm{Cu}-\mathrm{IH}$ & $41.82^{* *}$ & $\underline{1}$ & 7.76 & 139.59 \\
\hline & $\mathrm{Cu}-\mathrm{NH}$ & $26.92 *$ & \pm & 1.25 & 89.85 \\
\hline \multirow{5}{*}{ 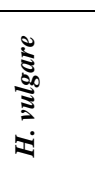 } & Control & 8.60 & 1 & 0.47 & 100.00 \\
\hline & $\mathrm{Cu}-\mathrm{IL}$ & $9.90^{*}$ & 1 & 0.21 & 115.12 \\
\hline & Cu-NL & 8.44 & 1 & 1.12 & 98.14 \\
\hline & $\mathrm{Cu}-\mathrm{IH}$ & $10.24 *$ & 1 & 1.18 & 119.07 \\
\hline & $\mathrm{Cu}-\mathrm{NH}$ & 8.90 & \pm & 1.03 & 103.49 \\
\hline
\end{tabular}

Statistical significance of differences compared to control: *, significant at $P<0.05$; **, significant at $P<0.01$.

\section{Discussion}

Although Copper is considered essential for physiological processes within plant cells, it persuades an obvious toxicity depending on its concentration and availability in soil. The present study showed the influence of ionic $\mathrm{Cu}$ and nonionic $\mathrm{Cu}$ on seed germination and antioxidant enzymes' activities of mung bean and barely. Non-ionic $\mathrm{Cu}$ particles were prepared by a bioprocess using $E$. coli volatile gases in a specific bioreactor. EDX analysis revealed that $\mathrm{Cu}$-particles comprised copper, sulfur, nitrogen, oxygen and carbon but with no measurable phosphorus that confirms the nonexistence of contamination by bacterial cells. According to our preceding studies (Essa et al., 2005 and Macaskie et al., 2007), the bacterial biogas included sulfur-based and nitrogen-based gaseous metabolites such as amines and dimethyl disulfide that are discharged during the excessive metabolic activity of the bacterial culture. Bacterial volatile sulfur molecules hold immense affinity to complex metal ions into insoluble metallo-sulfur compoundsd 
(Brummett et al., 2015; Essa and Khallaf, 2016). At the same time, the incidence of ammonia in E. coli biogas (confirmed using Nessler's solution) is in charge for altering $\mathrm{pH}$ value of copper solution in the direction of alkalinity (Table 1). Biogenic ammonia beside other amines liberated from $E$. coli culture have vital task in the complexation of copper ions into less soluble $\mathrm{Cu}$-particles. The complete chemical identification of $\mathrm{Cu}$-particles was not available in this investigation but EDX-analysis verified the incidence of nitrogen and sulfur in addition to carbon elements in the transformed $\mathrm{Cu}$-particles. These results are in agreement with our previous study (Essa and Mostafa, 2011; Essa et al., 2012) where some organo-sulfur and amine groups such as thiocarbonyl, disulfide and amine functional groups were spotted by Fourier-Transform Infrared Spectroscopy in the metal complexes resulting from the treatment of heavy metals with gaseous metabolites of oxic bacterial culture.

The obtained results revealed less toxicity of non-ionic $\mathrm{Cu}$ particles compared with the ionic $\mathrm{Cu}$ form in both low and high concentrations. The percentage of seed germination as well as all growth parameters analyzed; seedling lengths, fresh and dry weights, confirmed less toxicity of $\mathrm{Cu}$ particles. Inhibition of root elongation caused by heavy metals may be due to metal interference with cell division, chromosomal aberrations and abnormal mitosis (Jain et al., 2010 and Liu et al., 2003). Moreover, reduced seedling growth in metal treatments could be as a result of the reduction in meristematic cells (Kabir et al., 2008). The obtained results in this investigation revealed acceptable growth patterns with non-ionic $\mathrm{Cu}$ treatments indicating less toxicity of $\mathrm{Cu}$ in its non-ionic $\mathrm{Cu}$ form and hence $\mathrm{Cu}$ detoxification. Furthermore, in the present work, the antioxidant enzyme activities were significantly altered in response to $\mathrm{Cu}$ ions and non-ionic $\mathrm{Cu}$. For example, all antioxidant enzymes had higher activities in seedlings treated with ionic forms of $\mathrm{Cu}$. Moreover, non-ionic $\mathrm{Cu}$ forms could lower the POD and APX activities compared with the corresponding ionic forms but still the values higher than those of the controls. Similar to the present results, Nekrasova et al. (2011) reported decrease in CAT activity in E. densa at higher concentrations of copper ions. This can be explained by enzyme inactivation, might be, due to substitution of $\mathrm{Fe}^{2+}$ ion in its active center with $\mathrm{Cu}^{2+}$ ion (Hou et al., 2007; Mallick, 2004). Clearly, $\mathrm{Cu}$ ions inhibited the antioxidant enzymes more strongly, compared to non-ionic $\mathrm{Cu}$ particles (Nekrasova et al., 2011). In the present, a reason behind the APX inhibition in some cases of $\mathrm{Cu}$ treatments might be the lack of ascorbate due to presence of high amounts of $\mathrm{Cu}$ ions. It was reported previously that, copper ions promote rapid loss of ascorbate (Packer, 2001).

Several mechanisms were suggested by which the plant cells resist the toxic effects of heavy metals in particles form. One of those mechanisms is that plant cell walls present in natural settings, are primarily composed of carbon hydrate polymers, and are semi permeable. Thus, exotics need to penetrate through the cell wall prior to the membrane invagination. Limited size of pores in plant cell walls prevents larger molecules from free passing through cell wall (Carpita

Egypt. J. Bot., Vol. 56, No. 3 (2016) 
et al., 1979). Moreover, creating an apoplastic pool of $\mathrm{Cu}$ as a way for $\mathrm{Cu}$ detoxification affects chemical and structural changes in cell wall under the influence of $\mathrm{Cu}$ excess. Increasing the permeability of plant cell walls by metal exposure lead to create "holes", and then enter into the cells by penetrating through the "holes". After entering the cells, the non-ionic $\mathrm{Cu}$ particles are able to transport between cells via plasmodesmata which are microscopic channels of plants traversing the cell walls and enabling transport and communication between cells. Plasmodesmata or intercellular bridges were reported to be cylindrical channels with 40nm in diameter (Tilney et al., 1991). These plasmodesmata allow particles to pass from cell to another depending on their size causing less toxic effects than ionic $\mathrm{Cu}$. Furthermore, several investigations excluded dissolution from the main mechanisms regulating the toxicity of metalbased non-ionic particles (Nel et al., 2006). Even though the dissolution of nonionic $\mathrm{Cu}$ to cupric ions has a negligible effect in plant agar media, some amount of non-ionic $\mathrm{Cu}$ may dissolve to become cupric ions within the cell. Most toxic action results from the non-ionic $\mathrm{Cu}$ because of the presence of particles or aggregated nanoparticles within the cell (Lee et al., 2008). Another mechanism is changing the permeability of plasma membrane. Previously reported, damaging the plasma membrane through formation of $\mathrm{OH}$. radicles which can be achieved by traces of transition metal ions such as iron and copper (Packer, 2001). Reduction in seed germination can also be attributed to alterations of selection permeability properties of cell membrane. Alteration in plasma membrane permeability might be due to changes in membrane protein channels leading to metal ions passage and hence metal toxicity. It is well known that, cells become active produce the hydrolytic enzymes they begin to digest the stored food which is converted into soluble form and transported to the primary root and shoot tips for enzyme amylase which converts starch into sugar and proteases act on proteins. When the activities of hydrolytic enzymes are affected, the food does not reach to the primary root and shoot, thereby affecting the seedling growth (Kabir et al., 2008).

Another mechanism of $\mathrm{Cu}$ toxicity is through the generation of reactive oxygen intermediates $\left(\mathrm{H}_{2} \mathrm{O}_{2}, \mathrm{O}_{2}{ }^{-}, \mathrm{OH}\right.$, superoxide etc.) and then oxidative stress. Previously reported, exposure to excessive $\mathrm{Cu}$ ions leads to generation of oxidative stress in plant system (Gaetke and Chow, 2003). A suggested strategy to avoid toxicity of heavy metals is through the induction of antioxidant enzyme system and increase in the non-enzymatic antioxidants to reduce the oxidative damage related to excessive ROS formation caused by heavy metals (Verma and Dubey, 2003). In the present work, induced antioxidant enzyme activities were noticed in both ionic and non-ionic $\mathrm{Cu}$ treatments with different rations.This supports the theory of detoxification through management of oxidative stress. Antioxidant enzyme activities were highly induced in case of ionic $\mathrm{Cu}$ indicating more stressful conditions. Presence of ROS causes oxidative damage to biomolecules such as lipids, proteins, nucleic acids, etc. (Radwan et al., 2010 and Radwan, 2012). The transition metals such as $\mathrm{Cu}$ can act as specific cofactors for numerous metalloproteins because of their physical and chemical

Egypt. J. Bot., Vol. 56, No. 3 (2016) 
properties. It is involved in the maintenance of the functional and structural integrity of plant cells. Heavy metals exercise a detrimental influence on cells by binding to vital proteins and manage protein/enzyme functioning. In this experiment, reduction of soluble and total proteins contents was noticed in both ionic and non-ionic $\mathrm{Cu}$ treatments except for barley soluble protein contents. Comparing the contents of proteins, plants treated with non-ionic $\mathrm{Cu}$ had higher contents than those exposed to ionic $\mathrm{Cu}$. Obviously, $\mathrm{Cu}$ could reduce the total protein contents in mung bean and barley. Packer (2001) reported that copper cations are bound to proteins leading to their degradation. $\mathrm{Cu}$ toxicity is determined by binding to SH-groups in proteins, thereby inhibiting enzyme activity or protein function (Cohu and Pilon, 2010).

In the present work, a noticeable decrease in the amino acids content with $\mathrm{Cu}$ stress that might be involved in detoxification of copper (ionic or non- ionic). Organic acids, amino acids, or peptides are potential ligands for phytochelation of metals (Clemens, 2001). Moreover, amino acids such as citric, malic, and histidine are potential ligands for heavy metals and so could play a role in tolerance and detoxification (Clemens, 2001). In the cytoplasm, metals can either bind to free amino acids, the non proteinogenic nicotianamine, protein ligands that are rich in Cys residues, such as metallothioneins, metallochaperones, phytochelatins, and low molecular weight thiols (Callahan et al., 2006; Trampczynska et al., 2010).

\section{Conclusions}

This work highlights the effect of ionic and non-ionic $\mathrm{Cu}$ on germination and metabolism of barley grains and mung bean seeds. The non-ionic $\mathrm{Cu}$ was prepared using a bioprocess through bacterial biogases in a specific bioreactor. Barley and mung bean subjected to non-ionic $\mathrm{Cu}$ particles showed significantly lower toxicity than those treated with ionic $\mathrm{Cu}$. The reduced toxicity of non-ionic copper was attributed to the decline of copper capability to penetrate plant cells. Further studies are required to investigate the impact of this bioprocess on the toxicity of other metals in order to understand the collaborative impact of bacteria in diminishing heavy metals toxicity against plants in heavily polluted environment.

\section{References}

Anjum, N. A., Iqbal,A., Iram M., Mário, P., Armando,D. C., Eduarda,P., Shahid, U., Altaf, A. and Nafees K. A. (2012) Modulation of glutathione and its related enzymes in plants' responses to toxic metals and metalloids - a review. Environ. Exp. Bot., 75, 307-324.

Brummett, A.E., Schnicker, N.J., Crider, A., Todd, J.D. and Dey, M. (2015) Biochemical, kinetic, and spectroscopic characterization of Ruegeria pomeroyi DddW- a mononuclear iron-dependent DMSP lyase. PLoS ONE,10 (5), e0127288. http://Dol. org/10. 1371/journal. pone. 0127288 .

Egypt. J. Bot., Vol. 56, No. 3 (2016) 
Callahan, D. L., Baker, A. J., Kolev, S. D. and Wedd, A. G. (2006) Metal ion ligands in hyperaccumulating plants. J. Bio. Inorg. Chem., 11(1), 2-12.

Carpita, N., Sabularse, D., Montezinos, D. and Delmer, D. P. (1979) Determination of the pore size of cell walls of living plant cells. Science, 205(4411), 1144-1147.

Chandlee, J. and Scandalios, J. (1984) Analysis of variants affecting the catalase developmental program in maize scutellum. Theor. Appl. Genet., 69 (1), 71-77.

Clemens, S. (2001) Molecular mechanisms of plant metal tolerance and homeostasis. Planta, 212 (4), 475-486.

Cohu, C.M. and Pilon, M. (2010) Cell biology of copper. In: "Cell Biology of Metals and Nutrients. Ed. by Ru"diger H. and Mendel R.R. pp. 55-74. Springer, Berlin.

Dixit R., Malaviya D., Pandiyan K., Singh U. B., Sahu A., Shukla R., et al. (2015) Bioremediation of heavy metals from soil and aquatic environment: an overview of principles and criteria of fundamental processes. Sustainability 7, 21892212. $10.3390 /$ su7022189

Dupraz, C., Reid, R. P., Braissant, O., Decho, A. W., Norman, R. S. and Visscher, P. T. (2009) Processes of carbonate precipitation in modern microbial mats. Earth-Sci. Rev., 96 (3), 141-162.

Essa A. M. M. (2012) Effect of a continuous mercury stress on mercury reducing community of some characterized bacterial strains. Afr. J. Microbiol. Res. 6: (6) $1255-1261$

Essa, A.M., Abd-Alsalam, E.S. and Ali, R.M. (2012) Biogenic volatile compounds of activated sludge and their application for metal bioremediation. Afr. J. Biotechnol., 11(42), 9993-10001.

Essa, A. M., Macaskie, L. E. and Brown, N. L. (2005) A new method for mercury removal. Biotechnol. Lett., 27(21), 1649-1655.

Essa A. M. and Khallaf M. K. (2014) Biological nanosilver structures for the preservation of archaeological stones against microbial colonization. Int. Biodeter. Bioremed., 94, 31-37.

Essa A. M. and Khallaf M. K. (2016) Antimicrobial potentiality of consolidation polymers impregnated with copper nanoparticles. BMC Microbiol. 2016, 16:144 DOI: 10.1186/s12866-016-0766-8.

Essa, A. M. M. and Mostafa, S. M. M. (2011) Biomineralization of some heavy metals by cyanobacterial biogas. Egyp. J. Bot. 31, 112-121.

Fomina, M., Charnock, J. M., Hillier, S., Alvarez, R., Livens, F. and Gadd, G. M. (2008) Role of fungi in the biogeochemical fate of depleted uranium. Curr. Biol., 18 (9), R375-R377.

Gaetke, L.M. and Chow, C.K. (2003) Copper toxicity, oxidative stress, and antioxidant nutrients. Toxicol. 189 (1), 147-163. 
Garth, A. (2008) Analysing Data Using SPSS: A Practical Guide for Those Unfortunate Enough To Have to Actually do it. Sheffield Hallam University, 94.

Gill, S. S. and Tuteja, N. (2010) Reactive oxygen species and antioxidant machinery in abiotic stress tolerance in crop plants. Plant Physiol. Biochem., 48 (12), 909-930.

He, Z. and Yang, X. (2007) Role of soil rhizobacteria in phytoremediation of heavy metal contaminated soils. J. Zhejiang Univ. Sci. B., 8 (3), 192-207.

Hou, W., Chen, X., Song, G., Wang, Q. and Chang, C. C. (2007) Effects of copper and cadmium on heavy metal polluted waterbody restoration by duckweed (Lemna minor). Plant Physiol. Biochem., 45(1), 62-69.

Huang, Y., Tao, S. and Chen, Y. (2005) The role of arbuscular mycorrhiza on change of heavy metal speciation in rhizosphere of maize in wastewater irrigated agriculture soil. J. Environ. Sci. (China), 17(2), 276-280.

Jain, R., Srivastava, S., Solomon, S., Shrivastava, A. and Chandra, A. (2010) Impact of excess zinc on growth parameters, cell division, nutrient accumulation, photosynthetic pigments and oxidative stress of sugarcane (Saccharum spp.). Acta physiol. plant., 32(5), 979-986.

Jang, G. G., Jacobs, C. B., Gresback, R. G., Ivanov, I. N., Meyer, H. M., Kidder, M. and Moon, J. W. (2015) Size tunable elemental copper nanoparticles: extracellular synthesis by thermoanaerobic bacteria and capping molecules. J. Mater. Chem. C, 3(3), 644-650.

Jansen, E., Michels, M., Van Til, M. and Doelman, P. (1994) Effects of heavy metals in soil on microbial diversity and activity as shown by the sensitivity-resistance index, an ecologically relevant parameter. Biol. Fertility Soils, 17(3), 177-184.

Kabir, M., Iqbal, M. Z., Shafiq, M. and Farooqi, Z. (2008) Reduction in germination and seedling growth of Thespesia populnea L., caused by lead and cadmium treatments. Pak. J. Bot, 40(6), 2419-2426.

Lee, W. M., An, Y. J., Yoon, H. and Kweon, H. S. (2008) Toxicity and bioavailability of copper nanoparticles to the terrestrial plants mung bean (Phaseolus radiatus) and wheat (Triticum aestivum): Plant agar test for water-insoluble nanoparticles. Environ. Toxicol. Chem., 27(9), 1915-1921.

Liu, D., Jiang, W. and Gao, X. (2003) Effects of cadmium on root growth, cell division and nucleoli in root tip cells of garlic. Biol. Plant., 47 (1), 79-83.

Lowry, O.H., Rosebrough, N.J., Farr, A.L. and Randall, R.J. (1951) Protein measurement with the Folin phenol reagent. J. Biol. Chem., 193(1), 265-275.

MacAdam, J.W., Nelson, C. J. and Sharp, R. E. (1992) Peroxidase activity in the leaf elongation zone of tall fescue I. Spatial distribution of ionically bound peroxidase activity in genotypes differing in length of the elongation zone. Plant Physiol., 99 (3), 872-878.

Egypt. J. Bot., Vol. 56, No. 3 (2016) 
Macaskie, L., Creamer, N., Essa, A. and Brown, N. (2007) A new approach for the recovery of precious metals from solution and from leachates derived from electronic scrap. Biotechnol. Bioeng., 96(4), 631-639.

Mackie, K., Müller, T. and Kandeler, E. (2012) Remediation of copper in vineyards-a mini review. Environ. Pollut., 167, 16-26.

Mallick, N. (2004) Copper-induced oxidative stress in the chlorophycean microalga Chlorella vulgaris: response of the antioxidant system. J. Plant Physiol., 161(5), 591597.

Marschner, H. (1995) Mineral Nutrition of Higher Plants. Academic Press, London.

Michaud, A.M., Chappellaz, C. and Hinsinger, P. (2008) Copper phytotoxicity affects root elongation and iron nutrition in durum wheat (Triticum turgidum durum L.). Plant Soil, 310 (1-2), 151-165.

Moore, S. and Stein, W.H. (1948) Photometric ninhydrin method for use in the chromatography of amino acids. J. Biol. Chem., 176 (1), 367-388.

Nakano, Y. and Asada, K. (1981) Hydrogen peroxide is scavenged by ascorbate-specific peroxidase in spinach chloroplasts. Plant and cell physiol., 22 (5), 867-880.

Nekrasova, G., Ushakova, O., Ermakov, A., Uimin, M. and Byzov, I. (2011) Effects of copper (II) ions and copper oxide nanoparticles on Elodea densa. Russ. J. Ecol., 42(6), 458-463.

Nel, A., Xia, T., Mädler, L. and Li, N. (2006) Toxic potential of materials at the nanolevel. Science, 311(5761), 622-627.

Ouzounidou, G., Čiamporová, M., Moustakas, M. and Karataglis, S. (1995) Responses of maize (Zea mays L.) plants to copper stress-I. Growth, mineral content and ultrastructure of roots. Environ. Exp. Bot., 35 (2), 167-176.

Packer, L. (2001)"Handbook of Antioxidants" CRC Press.

Radwan, D.E.M. (2012) Salicylic acid induced alleviation of oxidative stress caused by clethodim in maize (Zea mays L.) leaves. Pestic. Biochem. Physiol., 102 (2), 182-188.

Radwan, D.E.M., Fayez, K.A., Mahmoud, S.Y. and Lu, G. (2010) Modifications of antioxidant activity and protein composition of bean leaf due to Bean yellow mosaic virus infection and salicylic acid treatments. Acta physiol. plant., 32 (5), 891-904.

Ruyters, S., Salaets, P., Oorts, K. and Smolders, E. (2013) Copper toxicity in soils under established vineyards in Europe. Sci. Total Environ., 443, 470-477.

Seshadri, B., Bolan, N. and Naidu, R. (2015) Rhizosphere-induced heavy metal (loid) transformation in relation to bioavailability and remediation. Journal of soil science and plant nutrition(AHEAD), 0-0.

Thounaojam, T. C., Panda, P., Choudhury, S., Patra, H. K. and Panda, S. K. (2014) Zinc ameliorates copper-induced oxidative stress in developing rice (Oryza sativa L.) 
seedlings. Protopl., 251(1), 61-69.

Tilney, L.G., Cooke, T.J., Connelly, P.S. and Tilney, M.S. (1991) The structure of plasmodesmata as revealed by plasmolysis, detergent extraction, and protease digestion. J. cell biol., 112 (4), 739-747.

Trampczynska, A., Küpper, H., Meyer-Klaucke, W., Schmidt, H. and Clemens, S. (2010) Nicotianamine forms complexes with $\mathrm{Zn}$ (II) in vivo. Metallomics, 2(1), 57-66.

Verma, S. and Dubey, R. (2003) Lead toxicity induces lipid peroxidation and alters activities of antioxidant enzymes in growing rice plants. Plant Sci., 164(4), 645-655.

Wang, X., Ma, Y., Hua, L. and McLaughlin, M. J. (2009) Identification of hydroxyl copper toxicity to barley (Hordeum vulgare) root elongation in solution culture. Environ. Toxicol. Chem., 28 (3), 662-667.

Zhang, X. (1992) Research methodology of crop physiology. Agri. Press, Beijing, 208211.

Zouboulis, A., Loukidou, M. and Matis, K. (2004) Biosorption of toxic metals from aqueous solutions by bacteria strains isolated from metal-polluted soils. Process Biochem., 39 (8), 909-916. 


\title{
إستخدام البكتيريا فى التخلص من سمية النحاس و أثر ذلك على مؤشرات إنبات الثعير و فول المانج
}

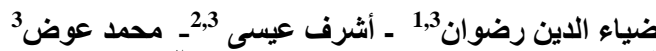

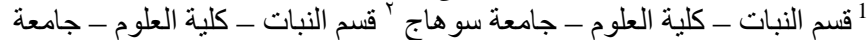

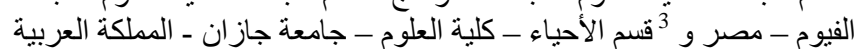

يحدث تر اكم أيونات النحاس في البيئة بتركيز ات مرتفعة كنتيجة للأنشطة البشرية

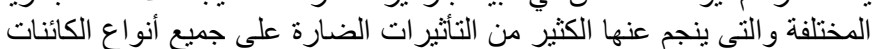

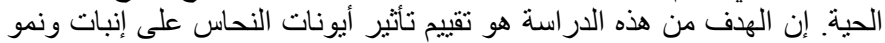

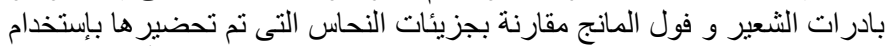

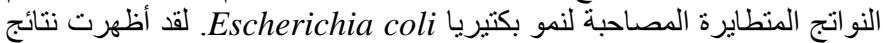

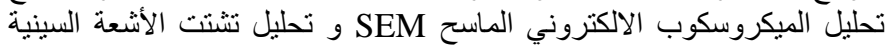
الطيفي EDX أن أيونات النحاس قد ترسبت على على شكل جزيئات مستطيلة ينر اول

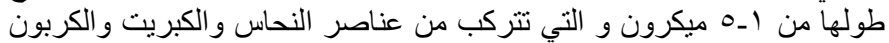

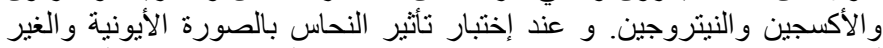

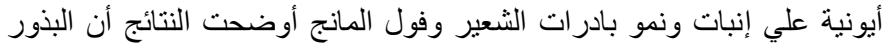

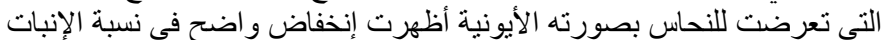

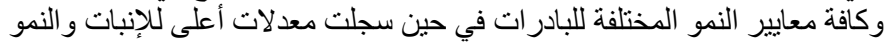

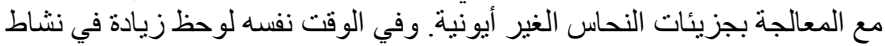

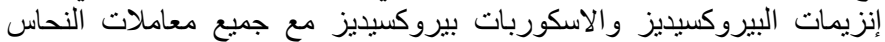

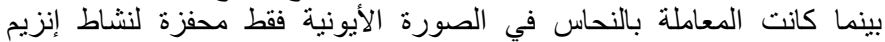

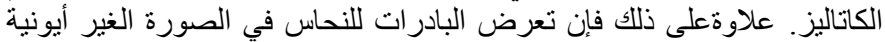

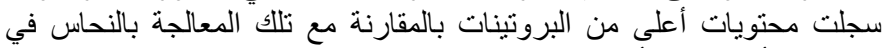

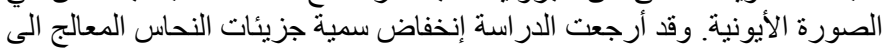

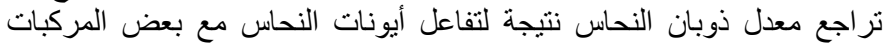

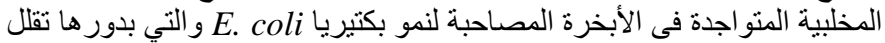
من إتاحية أيونات النحاس في بيئة نمو النباتات. 